\title{
СОВРЕМЕННЫЕ МЕТОДЫ ЛЕЧЕНИЯ РЕЦЕССИИ ДЕСНЫ
}

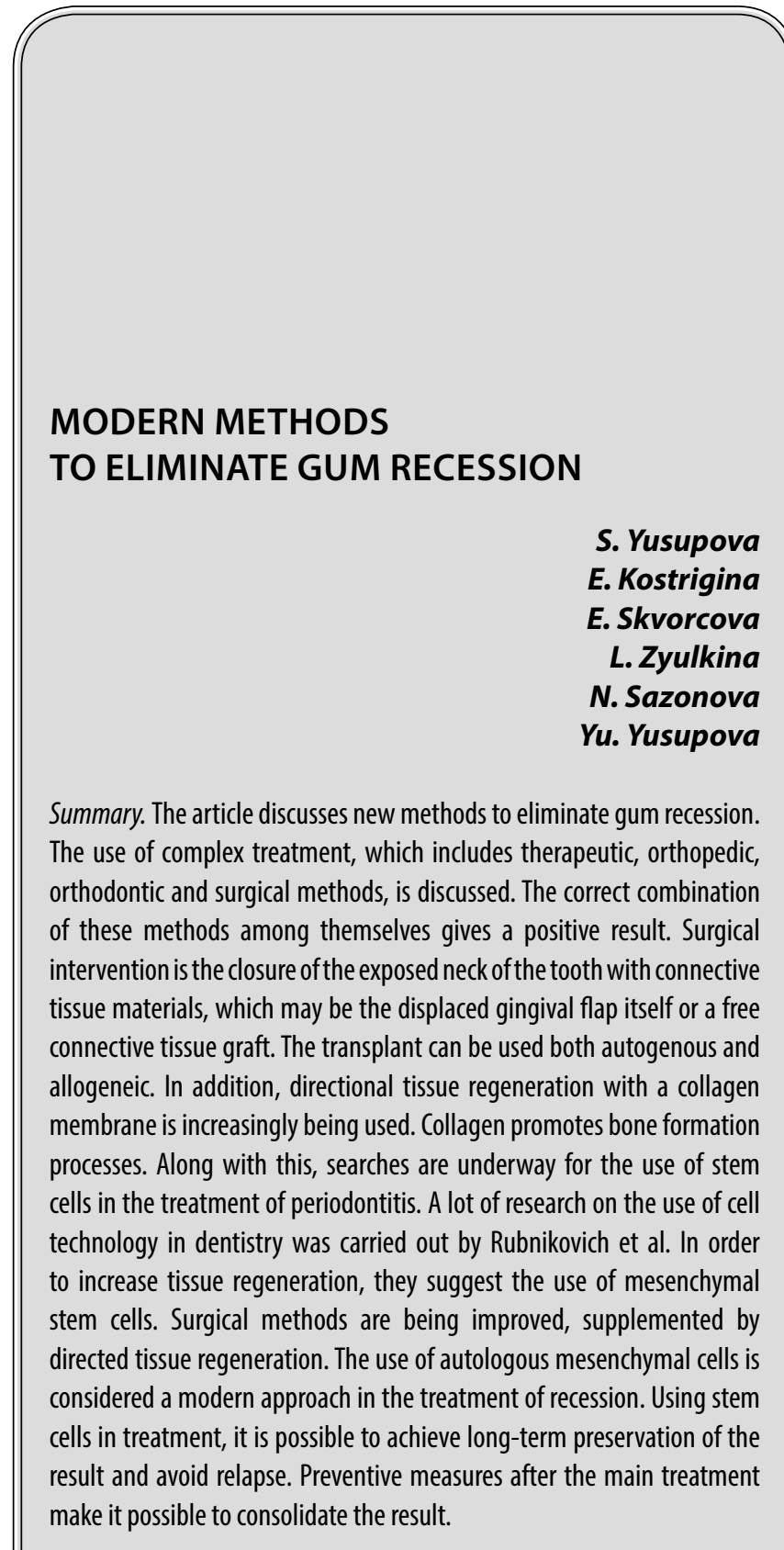

Keywords: periodontology, gum recession, mesenchymal stem cells.
Юсупова Сания Сулеймановна ФГБОУ ВО «Пензенский государственный университет»

iusupova.sania@yandex.ru

Костригина Екатерина Дмитриевна ФГБОУВО «Пензенский государственный университет»

Скворцова Елена Николаевна ФГБОУ ВО «Пензенский государственный университет»

Зюлькина Лариса Алексеевна ФГБОУ ВО «Пензенский государственный университет»

Сазонова Наталья Владиславовна ФГБОУВО «Пензенский государственный университет»

Юсупова Юлия Сулеймановна ФГБОУ ВО «Пензенский государственный университет»

Аннотация. В статье рассматриваются новые методы устранения рецессии десны. Обсуждается применение комплексного лечения, которое включает терапевтические, ортопедические, ортодонтические и хирургические методы. Правильное комбинирование этих методов между собой дает положительный результат. Хирургическое вмешательство представляет собой закрытие оголенной шейки зуба соединительнотканным материалом, в качестве которого может выступать сам смещенный десневой лоскут или же свободный соединительнотканный трансплантат. Трансплантат может использоваться как аутогенный, так и аллогенный. Кроме того, всё чаще применяется направленная тканевая регенерация с коллагеновой мембраной. Коллаген способствует процессам костеобразования. Наряду с этим ведутся поиски по использованию стволовых клеток в лечении пародонтита. Много исследований по применению клеточных технологий в стоматологии провели Рубникович и др. С целью повышения регенерации тканей они предлагают применение мезенхимальных стволовых клеток. Усовершенствуются хирургические методы, дополняясь направленной тканевой регенерацией. Современным подходом в лечении рецессии считается использование аутологических мезенхимальных клеток. Применяя стволовые клетки в лечении, удается добиться длительного сохранения результата и избежать рецидива. Профилактические мероприятия после основного лечения дают возможность закрепления результата.

Ключевые слова: пародонтология, рецессия десны, мезенхимальные стволовые клетки. 


\section{Ввеление}

$\Pi$ о разным данным рецессия десны является распространенной патологией заболеваний пародонта среди взрослого населения. Предъявляемые высокие требования к лечению способствуют поиску новых методов ее устранения [1-3]. Лечение заболеваний пародонта на сегодняшний день на основании проведенных исследований должно носить именно комплексных характер. Это означает, что подход к ликвидации рецессии десны также должен быть всесторонним. Именно слаженное командное лечение пациента специалистами приведет не только к быстрому выздоровлению, но даст больше гарантий на сохранение результата после проведенных манипуляций.

\section{Цель обзора}

Рассмотреть методы и технологии, применяемые для лечения рецессии десны, выявить новые способы ее устранения и методики использования клеточных технологий в пародонтологическом лечении.

В лечении рецессии выделяют консервативные методы и хирургические, но как показывает практика, становление современного постулата «комплексного лечения» приводит к объединению этих двух методов лечения. Использование только консервативных методов, конечно, способствует устранению дефекта, но не всегда обеспечивает длительный эффект [4]. Доказательством к этому можно считать выводы, приведенные в работах Бирагова и др. [5], где указывается, что после проведенного лечения краевой десны обогащенной тромбоцитами плазмой рецессия была устранена, но результат носил недолговременный характер. Спустя 9 месяцев шло постепенное ухудшение и возврат к изначальному состоянию.

Хирургическое вмешательство представляет собой закрытие оголенной шейки зуба соединительнотканным материалом, в качестве которого может выступать сам смещенный десневой лоскут или же свободный соединительнотканный трансплантат [6-8]. В хирургическом лечении может быть использован однослойный метод или двухслойный метод. Однослойный метод подразумевает использование прилежащих к зубу участков десны. В зависимости от способа смещения десны выделяют: латеральное и корональное смещение лоскута [9-11].

При двухслойном методе кроме смещения десневого лоскута стремятся повысить ее толщину и увеличить устойчивость. С этой целью используют сое- динительнотканный трансплантат (СТТ). Двухслойная методика имеет следующие модификации: латеральное смещение лоскута с СТТ; методика двойного сосочкового лоскута СТТ; корональное смещение лоскута с СТT; тоннельная техника с СТT; конвертная техника с СТТ [12].

\section{Метолика}

коронального смещения лоскута с использованием соединительнотканного трансплантата считается «золотым стандартом» лечения рецессии. Она впервые была предложена Langer в 1985 году. Raetzke смог модифицировать ее, устранив недостаток вертикальных послабляющих разрезов и создав методику «конверта», где соединительнотканный трансплантат укладывался под коронально смещенный лоскут [12]. Zabelgui et al. соединили несколько «конвертов» и создали тоннельную методику, при выполнении которой десневые сосочки оставались целыми. Azzi в 2002 году усовершенствовал тоннельную методику так, что при ней не только сохранялись десневые сосочки, но и выполнялись внутрибороздковые разрезы вместо горизонтальных разрезов. Методика Azzi также была дополнена Otto Zuhr в 2007 году [13, 14].

Авторы статьи [15] считают, что тоннельная методика с СТТ обладает большой вероятностью устранения дефекта десны. И все же она сложна в проведении, с чем соглашаются другие исследователи [13]. Недостаток методики заключается в создании дополнительного операционного поля для получения СТТ, что также может привести к осложнениям.

С целью разрешения этой проблемы авторы [16] предлагают использовать СТТ с ретромолярной области. Соединительнотканный трансплантат над ретинированными зубами может применятся для устранения рецессии десны. При этой операции причинами ее проведения будут выступать два факта: необходимость получения СТТ и удаление третьего моляра с удалением слизистой оболочки над ней. Данный подход вызывает интерес пациента, так и врача.

Вместо аутогенного можно использовать аллогенный трансплантат. В качестве алллогенного трансплантата применяется твердая мозговая оболочка «Лиопласт». Методика проведения трансплантации заключается в следующем. Сначала берутся показатели глубины рецессии. После чего приступают к хирургической части. Выполняют разрез от центральной рецессии и внутрибороздковый разрез, создавая слизисто-надкостничный лоскут и мобилизуя его. Твердая мозговая оболочка «Лиопласт» (TMO) заранее перфорируется и фиксируется резорбтивными узло- 
выми швами в межзубных промежутках. Сверху ТМО укрепляется и фиксируется слизисто-надкостничным лоскутом. В результате данной методики наблюдается полное восстановление утраченной части десны и увеличение ее объема в два раза [17].

В качестве дополнения к хирургическим методам применяют остеопластические препараты: Emdogain Gel из группы эмалевых матричных протеинов и тромбоцитарный концентрат [18-20]. Emdogain Gel способствует возникновению функционального прикрепления в области рецессии десны. Но положительный результат достигается только в том случае, если сохраняется герметичная связь между ранее оголенной поверхностью корня и восстанавливаемыми тканями. Тромбоцитарный концентрат содержит семь основных факторов роста: фактор роста эпителия, трансформирующий фактор роста, фактор роста эндотелия сосудов и тромбоцитарный фактор. Эти биологические медиаторы ускоряют процессы заживления ран, стимулируют ангиогенез и остеогенез [21-23].

Совместное использование тромбоцитарного фактора и Emdogain Gel дает положительную динамику в лечении рецессии десны, что подтверждается гистологическими срезами, полученными входе эксперимента исследователями Толмаковой С. И. и др. [20].

Хирургические методики на сегодняшний день усовершенствуются. Уже всё чаще используется направленная тканевая регенерация при помощи коллагеновой мембраны «КОЛлОСТ». Много современных работ, доказывающих целесообразность ее применения, представлено на данное время. Это свидетельствует о том, что на этапе хирургического лечения не просто возвращают десневую ткань на первоначальное положение посредством собственных тканей, но создают условия для лучшей фиксации и увеличения ее толщины [24-26].

Коллагеновая мембрана применяется в направленной тканевой регенерации, суть которой заключается в восстановлении природной топографии тканей и их функции. Регенерация эпителиальных клеток лоскута происходит быстрее клеток периодонта. При этом происходит врастание эпителия лоскута вглубь пародонтального кармана, что приводит к медленному формированию нового прикрепления, источником которого являются клетки-предшественники периодонта. Коллагеновая мембрана представляет физический барьер, который влияет на правильное формирование топографии десневого края, посредством ограничения десневого лоскута и тканей периодонта [27]. Кроме того, одним из пусковых факторов в остановке кровотечения является коллаген. Он активирует тромбоциты, которые меняют свою форму и высвобождают различные биологически активные вещества. Эти вещества способствуют конформации гликопротеинов в мембране тромбоцитов, и тем самым происходит связывание фибрина с тромбоцитами. Этим объясняется кровоостанавливающий эффект коллагеновой мембраны. Кроме того, образовавшийся сгусток с фибриновыми нитями служит хорошим каркасом для прорастания клеток сосудов.

Коллагеновая мембрана является биоразлагаемой, деградирует к 24-й неделе и состоит и коллагена I типа vожет фиксироваться разными способами [27].

Одним из эффективных решений при лечении рецессии десны является применение ацелюлярных дермальных матриксов, таких как «КОЛЛОСТ», которые выступают в качестве тканевых кондукторов, способствующих направленному росту эпителия в местах дефицита и низкого качества мягких тканей [27].

Также появилась гелевая форма препарата «КОЛлОСТ». Было проведено исследование [28], в котором курс лечения состоял из 3 процедур, по 1 процедуре в каждом месяце. За 14 дней до начала лечения была проведена аллергическая проба путем введения внутрикожно в область предплечья 0,1 мл геля, был получен отрицательный тест. На основе исследования [28] был сделан вывод, что хороший результат лечения показало применение 7\% геля препарата «КОЛлОСТ».

Многочисленные научные исследования свидетельствуют о перспективности применения клеточных технологий в стоматологии [29-31].

Применение аллогенных и аутологичных мезенхимальных стволовых клеток для регенерации позволит добиться желаемых результатов лечения на длительный срок [32-34].

Исследования F.M. Chen и др. показали, что имплантация аутологичных стволовых клеток не вызвала значимых побочных эффектов [35]. K. Zanwar и др. отметили эффективность стволовых клеток при лечении рецессии десны. Наилучший результат наблюдался через 12 нед. после проведенной трансплантации стволовых клеток [36].

И.И.Степанова и др. проводили исследования, в которых для устранения рецессии десны применялись аутофибробласты. Источником культуры фибробластов послужили ткани слизистой оболочки в области преддверия ротовой полости, твердого неба или ретромолярного пространства. [37,38]. 
Много исследований по применению клеточных технологий в стоматологии провели Рубникович и др. [39-41]. С целью повышения регенерации тканей они предлагают применение мезенхимальных стволовых клеток. В ходе их исследования у пациентов, которым проводили периодонтологическое и ортодонтическое лечение с использованием аутологичных мезенхимальных стволовых клеток, в 94\% случаев был получен хороший результат, характеризующийся увеличением объема десны и улучшением микроциркуляции тканей периодонта. Авторы утверждают, что длительный эффект лечения был достигнут именно благодаря комплексному лечению, где использовались ортодонтическое, периодонтологическое лечение и применение стволовых клеток для улучшения регенераторных способностей тканей [42].

Был предложен М.Д. Перовой и др. метод, восстанавливающий костную ткань и ткани периодонта при помощи аутологичной васкулярно-клеточной фракции. Эта фракция содержит мезенхимальные стволовые клетки, полученные из жировой ткани. Согласно предложенной методике проводится кюретаж в области, где будет произведено оперативное вмешательство, и обработка зубной поверхности лимонной кислотой с $\mathrm{pH}=1,0$. На подготовленную поверхность помещается трансплантат, представляющий собой мезенхимальные стволовые клетки жировой ткани, а сверху накладывается нерезорбируемая барьерная мембрана. При рецессии десны вместо барьерной мембраны используется небный аутологический лоскут. Данная методика была проведена у 18 пациентов. Полученные результаты показали эффективность, которая заключалась в ускорении заживления, в значительном сокращении сроков лечения пациентов с тяжелыми болезнями периодонта [43].

\section{Зак^ючение}

Таким образом, в ходе библиографического обзора было установлено, что терапевтические и хирургические методы усовершенствуются в соответствии с предъявляемыми новыми требованиями к лечению. Важным шагом следует считать, постепенное обоснованное внедрение клеточных технологий, пока как дополнительных, к основному лечению. Стволовые клетки повышают регенеративную способность тканей, что сказывается на течении реабилитационного периода и, самое важное, на состоянии тканей после лечения. Результат сохраняется длительное время, а вероятность рецидива снижается. Всё это доказывает актуальность проводимых исследований по применению клеточных технологий в стоматологии. Кроме того, все новые методики и дополнения к имеющимся направлены на повышение эстетичности в зоне проведенных манипуляций, так как данный критерий на сегодняшний день является очень важным для пациента.

\section{ЛИТЕРАТУРА}

1. З Зюлькина Л.А., Кобринчук К. Ю., Иванов П. В., Капралова Г. А. Механизмы возникновения и методы устранения рецессии десны // Современные проблемы науки и образования. 2017;1:54.

2. Ганжа И.Р., Модина Т. Н., Хамедова А. М. Рецессия десны: диагностика и методы лечения.—Самара: 000 ИПК «Содружеств0».2007;84.

3. Мусиенко А.И., Русанов В.П., Мирзакулова У.Р., Мусиенко А. А., Мусиенко С. И. Факторы развития и способы хирургического лечения рецессии десны. Уральский медицинский журнал.2015;6(129):71-76.

4. Зюлькина Л.А., Сапожникова Ю.С. Пути совершенствования хирургических методов лечения рецессии десны. Сборник статей по материалам Международных научно-практических конференций. под ред. А. И. Вострецова. Нефтекамск. 2017; 404-407.

5. Бирагова А.К., Беленчеков А. А., Епхиев А. А. Эффективность лечения краевой рецессии десны с применением инъекций обогащенной тромбоцитами плазмы. Вестник новых медицинских технологий.2018;2:1-1.

6. Дурново Е.А., Шашурина С. В., Беспалова Н. А., Андреева М. В. Сравнительный анализ клинической эффективности различных методов устранения рецессий десны. Ближайшие и отдаленные результаты. Успехи современной науки и образования. 2016;9:174-181.

7. Гусарина Е.И., Бородулина И. И., Чибисова М. А., Зубарева А. А. Оценка эффективности использования двухэтапной методики устранения рецессий десны. Институт стоматологии. 2017;1(74):34-37.

8. Черныш В.Ф., Чепик Г.С., Иванников А. А. Устранение локальной рецессии десны пластикой угловым муко-гингивальным лоскутом. Пародонтология. 2010;3(56):32-37.

9. Трунин Д.А., Нестеров А.М., Садыков М.И., Костионова-Овод И. А. Способ устранения локальной рецессии десны. Уральский медицинский журнал. 2019;12(180):14-17.

10. Беспалова Н.А., Дурново Е. А., Шашурина С. В. Возможности хирургического устранения и профилактики рецессии десны с использованием различных видов трансплантационной техники. Медицинский альманах. 2015;3(38):150-155.

11. Мусиенко А.И., Попов А. К. Рецессия десны и метод ее устранения. Институт стоматологии. 2006;1(30):90-91.

12. Смирнова С.С., Выбор метода устранения рецессии десны. Проблемы стоматологии. 2008; 4:13-19. 
13. Баландина М.А., Кобозев М. И., Мураев А. А., Иванов С. Ю., Сравнительный анализ эффективности хирургических методик закрытия множественных рецессий десны. Журнал научных статей Здоровье и образование в XXI веке. 2016;18(1):103-106.

14. Zuhr 0 , Baumer D, H€urzeler M. The addition of soft tissue replacement grafts in plastic periodontal and implant surgery: critical elements in design and execution. J Clin Periodontol. 2014; 41 (Suppl. 15): S123-S142. doi:10.1111/jcpe.12185.

15. Гордеева А.И., Рагулина Д. Д., Саютина Л. В., Современные аспекты лечения рецессии десны. Международный студенческий вестник. $2018 ; 4(1): 130-133$.

16. Баландина М.А., Кобозев М. И., Мураев А. А., Иванов С. Ю. Применение свободного соединительнотканного трансплантата, полученного в области третьих моляров, при устранении одиночной рецессии. Журнал научных статей Здоровье и образование в XXI веке. 2016;18(1):107-111.

17. Носова М.А., Эффективность операции коронального смещения с пластикой твердой мозговой оболочкой «ЛИоПЛАСТ» для устранения множественных рецессий десны. Аспирантский вестник Поволжья. 2016;5-6:103-106.

18. Jin Jiang, Golnaz Goodarzi, Jianing He, Haitao Li, Kamran E Safavi, Larz S. W. Spångberg, Qiang Zhu. Emdogain-gel stimulates proliferation of odontoblasts and osteoblasts. Journal of clinical periodontology. 2006; Dec;102 (5): 698-702. D0l: 10.1016/j.triple0.2006.02.011

19. Февралева А.Ю., Давидян А. Л. Устранение рецессии десны планирование, современные методы лечения, прогноз. ПолиМедиаПресс, $2007 ; 1: 150$.

20. Токмакова С.И., Чудова Л. В., Бобров И. П. Патоморфологическое обоснование комплексного применения препарата Emdogain Gel и тромбоцитарных факторов L роста при хирургическом лечении рецессии десны. Пародонтология. 2008; 3(48):10-13.

21. Ганжа И.Г., Модина Т. Н., Болбат М. В. Закрытие рецессии десны с использованием факторов роста // Пародонтология. 2005;3(36): 34-37.

22. Меджидов М.Н., Дмитриева Л. А. Оценка эффективности использования препаратов тромбоцитарного фактора роста-ББ и системы фибрин-фибронектина в хирургическом лечении локальной рецессии десны (часть II). Институт стоматологии. 2006; 3(32):54-55.

23. Юрченко М.Ю., Шумский А. В. Хирургическое лечение пародонтита с применением обогащенной тромбоцитами плазмы. Клиническая стоматология. $2003 ; 2: 46-48$.

24. Шенгелия Е.В., Иорданишвили А. К., Музыкин М. И., Балин Д. В. Результаты хирургического лечения стоматологических заболеваний с применением биопластического коллагенового материала. Пародонтология. 2014; 3 (72):73-78.

25. Кабанова А.А., Кабанова С. А., Авезклычев Б. Д., Минина А. Н., Чернина Т. Н., Таранко А. П., Стельмаченок С. С. Материал «КоллоСТ» в практике стоматолога-хирурга. Достижения фундаментальной, клинической медицины и фармации Материалы 72-й научной сессии сотрудников университета. Витебский государственный медицинский университет. 2017;122-123.

26. Нейзберг Д.М., Силина Э.С., Пачкория М.Г. Мембраны на основе ацеллюлярного коллагенового матрикса при реконструкции комбинированных дефектов альвеолярного гребня методом направленной регенерации тканей. Медицинский алфавит. 2019; 23 (398):24-28.

27. Метод направленной тканевой регенерации в пародонто-альвеолярной реконструкции. Под ред. Л. Ю. Ореховой.— М.: Литтерра, 2017.

28. Максимова Н. В. Применение гелевой формы препарата «КОллоСТ» для устранения рецессии десны у пациентов с несъемными ортопедическими конструкциями в эстетически значимой зоне. Уральский медицинский журнал. 2017; 4(148): 127-129.

29. Алексеева И.С., Волков А.В., Кулаков А.А., Гольдшейн Д. В. Клинико-экспериментальное обоснование использования комбинированного клеточного трансплантата на основе мультипотентных мезенхимных стромальных клеток жировой ткани у пациентов с выраженным дефицитом костной ткани челюстей. Клеточная трансплантология и тканевая инженерия. 2012;1: 97-105.

30. Алямовский В.В., Шестакова Л. А., Ярыгин Е. И., Шмидт П. А., Лазаренко Л. И. Использование стволовых клеток крови плода крысы при воспалительно-деструктивных процессах в тканях пародонта. Институт стоматологии. 2014;1 (62):103-105.

31. Бухарова Т.Б., Арутюнян И. В., Шустров С. А., Алексеева И.С., Федюнина И. А., Логовская Л. В., Волков А. В., Ржанинова А. А., Григорьян А. С., Кулаков А. А., Гольдштейн Д. В. Тканеинженерная конструкция на основе мультипотентных стромальных клеток жировой ткани и материала «0стеоматрикс» для регенерации костной ткани. Клеточные технологии в биологии и медицине.2011; 3:167-170.

32. Мусиенко А.И., Мусиенко С. И., Кушнир Д. В., Мусиенко А. А. Комплексный подход к планированию лечения заболеваний пародонта фактором роста /. Стоматология Казахстана.2014; 3(4):67-68.

33. Перова М.Д., Гайворонская Т. В., Карпюк В. Б., Тропина А. В., Перова М. Д. Характеристика степени замещения пародонтальных дефектов разной топографии после аутотрансплантации васкулярностромальноклеточной фракции липоаспирата. Кубанский научный медицинский вестник. 2013;1:142-148.

34. Рубникович, С.П., Хомич И. С. Костные трансплантаты и заместители для устранения дефектов и аугментации челюстных костей в имплантологии и периодонтологии. Стоматолог. Минск. 2014; 1(12):77-86.

35. Chen F.M. [et al.] Treatment of periodontal intrabony defects using autologous periodontal ligament stem cells: a randomized clinical trial. Stem Cell Res.\& Ther. 2016;7:33.

36. Zanwar K. [et al.] Comparative evaluation of efficacy of stem cells in combination with PLA/PGA membrane versus sub-epithelial connective tissue for the treatment of multiple gingival recession defects: a clinical study. J. of Stem Cells. 2014; 9: 253-267.

37. Грудянов А.И., Зорин В.Л., Зорина А. И., Степанова И. И. Клеточные технологии в пародонтологии. Стоматология.2009; 1:71-73.

38. Грудянов А.И., Степанова И. И., Зорин В. Л., Зорина А. И., Копнин П. Б., Черкасов В. Р. Применение аутогенных фибробластов слизистой оболочки полости рта человека для устранения рецессии. Стоматология. 2013; 1:21-25.

39. Рубникович С.П., Волотовский И. Д., Денисова Ю. Л., Владимирская Т. Э., Андреева В. А., Квачева 3. Б., Панасенкова Г. Ю. Экспериментальное обоснование применения клеточных технологий для регенерации тканей периодонта. Медицинский журнал. 2018; 4:81-86.

40. Рубникович С.П., Волотовский И. Д., Денисова Ю. Л., Андреева В. А., Панасенкова Г. Ю., Квачева З. Б. Применение клеточных технологий в лечении пациентов с рецессией десны. Медицинский журнал. 2019;2(62): 101-107. 
41. Рубникович С.П., Волотовский И. Д., Денисова Ю. Л., Андреева В. А., Панасенкова Г. Ю. Клиническое обоснование применения стволовых клеток в лечении рецессии десны. Доклады Национальной академии наук Беларуси. 2019; 4: 476-484.

42. Рубникович С.П., Панасенкова Г. Ю. Применение стволовых клеток в стоматологии. Стоматология. Эстетика. Инновации. 2019; 2:144-155.

43. Способ восстановления кости альвеолярного гребня челюсти и тканей пародонта с редуцированным регенераторным потенциалом: пат. RU2320285 / М. Д. Перова, В. Б. Карпюк, А. В. Фомичева, Е. А. Фомичева, М. Г. Шубич.- Опубл. 27.03 .2008

( Ю Юсупова Сания Сулеймановна ( iusupova.sania@yandex.ru ), Костригина Екатерина Дмитриевна,

Скворцова Елена Николаевна, Зюлькина Лариса Алексеевна,

Сазонова Наталья Владиславовна, Юсупова Юлия Сулеймановна.

Журнал «Современная наука: актуальные проблемы теории и практики»

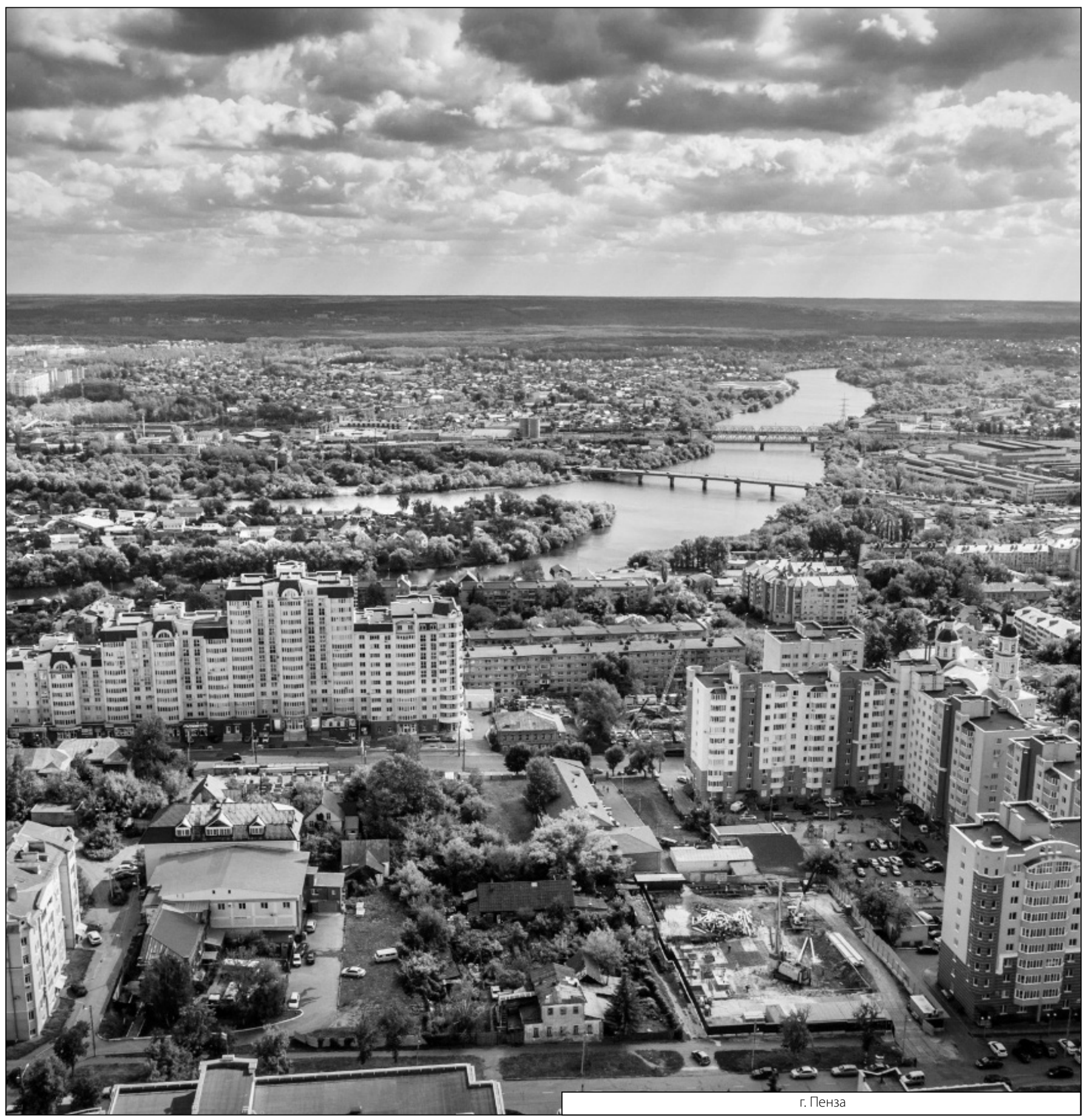

